\title{
Comparison of the Models in Choice Experiments Method Application for Watershed Afforestation in Southern Turkey
}

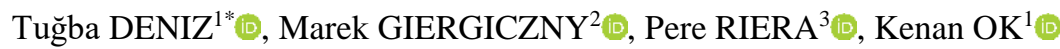 \\ ${ }^{1}$ Istanbul University-Cerrahpasa, Department of Forest Economics, Istanbul, TURKEY \\ ${ }^{2}$ University of Warsaw, Department of Economic Sciences, Warsaw, POLAND \\ ${ }^{3}$ Institute of Environmental Science and Technology (ICTA), Barcelona, SPAIN \\ *Corresponding Author: denizt@istanbul.edu.tr
}

Received Date: 30.04 .2020

Accepted Date: 09.11.2020

Abstract
Aim of study: In this study, the value estimates of the four benefits (preventing floods, reducing soil
erosion, increasing dam life and access to quality spring water) created by erosion control activities are
compared according to different models and the determination of these models.
Area of study: The Çakıt Stream Watershed was selected as a study area.
Material and methods: In this study, the data collected by Deniz (2012) to apply Choice Experiments
Method were used. While Deniz (2012) had estimated the marginal values of the benefits based on
Multinomial Logit Model, in this study, the estimations were separately made in order to compare the
results of Deniz (2012) using both another Multinomial Logit Model with different variables and Mixed
Multinomial Logit Model.
Main results: Although the marginal values found by using Mixed Multinomial Logit Model are
different from the estimations found with Multinomial Logit Model, the relationships among the variables
did not change. Determination of Mixed Multinomial Logit Model is bigger (Pseudo-R $\left.{ }^{2}=0.548\right)$ than
Multinomial Logit Models (0.251 and 0.071).
Highlights: In the study, it was observed that as the models used to determine the value of the erosion
control service changed, the magnitude of the estimated values also changed.
Keywords: Choice Experiments Method, Çakit Stream Watershed, Erosion Control, Multinomial Logit
Model, Mixed Multinomial Logit Model, Valuation.
Türkiye'nin Güneyindeki Havza Ağaçlandırmalarına UygulanmıŞ
Seçim Deneyleri Yönteminde Kullanılan Modellerin
Karşılaştırılması

$\ddot{O} \mathbf{z}$

Çalışmanın amacı: Bu çalışmada, erozyon kontrolü çalışmalarının yarattığı dört faydanın (sellerin önlenmesi, toprak erozyonunun azaltılması, baraj ömrünün ve kaliteli kaynak suyuna erişimin artırılması) farklı modellere göre değer tahminleri ve bu modellerin açıklayıcılıkları karşılaştııılmıştır.

Çalışma alanı : Çakıt Çayı Havzası araştırma alanı olarak seçilmiştir.

Materyal ve yöntem: Bu çalışmada, Seçim Deneyleri Yöntemini uygulamak için Deniz (2012) tarafından toplanan veriler kullanılmıştır. Deniz (2012), söz konusu faydaların marjinal değerlerini Multinomial Logit Modele göre tahmin etmişken, bu çalışmada farklı değişkenlerle kurulan başka bir Multinomial Logit Model ile Karma Çok Durumlu Logit Model kullanılarak iki ayrı tahmin daha yapılmış ve bu üç modelin sonuçları karşılaştırılmıştır.

Temel sonuçlar: Karma Çok Durumlu Logit Modeli kullanılarak bulunan marjinal değer tahminleri, Multinomial Logit Modelinde bulunan tahminlerden farklı olmasına karşın değişkenler arasındaki ilişkiler değişmemiştir. Karma Çok Durumlu Logit Modelin açıklayıcıllı̆ı (Pseudo- ${ }^{2}=0.548$ ), Multinomial Logit Modellerden ( 0.251 ve 0.071$)$ daha büyüktür.

Araştırma vurguları: Çalışmada, erozyon kontrolü hizmetinin değerini belirlemek için kullanılan modeller değiş̧tikçe, tahmin edilen değerlerin büyüklüklerinin de değiştiği görülmüștür.

Anahtar Kelimeler: Seçim Deneyleri Yöntemi, Çakıt Çayı Havzası, Erozyon Kontrolü, Çok Durumlu Logit Model, Karma Çok Durumlu Logit Model, Değer Belirleme. 


\section{Introduction}

In the National Forestry Program of Turkey (2004-2023), one of the forestry policies is to expand forest lands. In this scope, erosion control, rangeland rehabilitation and afforestation activities are given priority to combat desertification and to protect water and soil resources (MoEF, 2004). On the other hand, in the Strategic Plan of Ministry of Agriculture and Forestry (20192023), one of the main objectives is to combat climate change, desertification and erosion efficiently. Another objective is to protect, improve, and manage of water resources sustainability (MoAF, 2019).

Erosion control, rehabilitation of degraded forest land, afforestation and rangeland works have been started in 1946 in Turkey. In 1969, General Directorate of Afforestation and Erosion Control was established for planning and programming afforestation and erosion control activities (GDAEC, 2008).

Afforestations have three purposes such as production (economic purposes); conservation, hydrologic and habitat rehabilitation (ecologic purposes); aesthetic, recreation, and environment conservation (social purposes) (GDAEC, 2008). To determine benefits of afforestation activities, valuation studies are important for both society and resource managers. Resource managers would like to define benefits of an afforestation program to compare different projects under the specific budget constraint. This is vital for an efficient resource management. Forest ecosystems produce a lot of goods and services which has market or non-market values. Especially, estimating the values of non-market services is difficult. There are different methods to determine nonmarket value of services.

In Turkey, valuation studies were generally carried out on recreation, wildlife, hunting, water quality, aesthetics etc. These studies used different methods such as Market Prices, Production Function, Averted Expenditures, Travel Cost Method (TCM), Replacement Cost Method, Contingent Valuation Method (CVM), Hedonic Pricing Method (HPM) and Choice Experiments Method (CEM).

Bann \& Clemens (2001) prepared a study in the scope of Forest Sector Review. In the study, non-wood forest products were considered as an externality and tried to estimate monetary values of wildlife, recreation, watershed management, carbon sequestration, and genetical resources etc. in Turkey. According to this, the value of positive externalities was accounted approximately 496 million US\$ using market prices, replacement method, and damage cost avoided method.

Pak (2002) estimated recreational use values of 7 forest recreation sites from Trabzon and Kahramanmaraş using TCM and CVM. According to results, the annual consumer surplus values varying between 1.3 billion €/ha (Soğuksu) and 14.2 billion $も$ (Dülükbaba) were calculated. Annual willingness to pay (WTP) values varying between approximately 50 million $€$ (Çamburnu) and 1.03 billion $€$ (Dülükbaba) for the current situation of 7 sites were estimated by CVM in same study.

Türker et al. (2005) which is a technical report of The Total Economic Value (TEV) of Turkey Forests which was prepared in the scope of Mediterranean Forests Externalities(MEDFOREX) Project. In this report, the TEV of the forests in Turkey was calculated annual as 1071088000 US\$. In addition, Pak et al. (2010) determined the net total economic value of Turkish Forests as 1620459352 US\$, annually. Gürlük \& Ward (2009) determined the average water values for agriculture, urban and recreation using derived demand function in Nilüfer Watershed in Bursa. According to the results, the average water values were calculated as $31 € / \mathrm{m}^{3}$ for urban use and for irrigation $3.9-4.6 € / \mathrm{m}^{3}$.

Pehlivanoğlu (2010) estimated the economic value of improved water quality in Bartın River. Annual average WTP was estimated as 57.58 for per household and 15.27も per capita.

Özdemir \& Baycan-Levent (2010) used CVM for community-based watershed management in Beyşehir Lake. The results showed that the total value of improving Beyşehir Lake's water quality was estimated approximately as 2.09 million $€$ per year. Tolun et al. (2012) studied socioeconomic review to improved water quality with CVM for İzmit Bay Coastal System. The average WTP was calculated $18.7 €$. Can \& Alp 
(2012) tried to determine the value of environmental improvements in Göcek Bay, a protected marine area. The WTP for improvements in water quality was determined as $18 € /$ month/person and for improvements in marine life was calculated 14.8 も/month/person.

Kaya \& Özyürek (2015) estimated the economic values for scenic beauty of the Middle East Technical University Forest in Ankara by using HDM. The economic values of scenic beauty of the forest were estimated as 15.535-23.315 も per dwelling, 8-12 million も per year and totally 101-151 million $€$ for target housing market.

Croitoru et al. (2016) estimated the economic value of water in Beyşehir Lake, the largest freshwater lake in Turkey. The results showed that the economic value of water is about seven times higher than its financial value. Whereas financial value is value of only marketable goods and services, economic value is total value of market and non-market goods and services. The economic value of water allocated for municipal use $\left(5 \hbar / \mathrm{m}^{3}\right)$ is substantially greater than that supplied for irrigation $\left(0.5 € / \mathrm{m}^{3}\right)$.

Özmış \& Tolunay (2017) accounted the value of some indirect benefits which created by erosion control activities in Burdur Region. They were used same attributes such as preventing of loss of soil, reducing flood risk, extending the life of the dam and increasing access to high-quality spring water. Data on erosion control service were collected by the survey. They estimated the average consumer surplus as 17.12 per household and the total annual economic value as 125290768 using CVM.

Kaya et al. (2018) aimed to quantify the regional forest recreation using the regional TCM. Two regional demand functions based on the regional TCM were estimated for forest recreation activities, mainly picnicking, with multiple regression analysis. Then secondstage demand curve was drawn with hypothetical increases in the travel costs by using the regional recreation demand functions. This curve formed using the data obtained from all the users shows that the travel cost increasing up to 503 も has positive effects on revenues from the forest recreation sites as the arc elasticity values in this range are between 0.01 and 0.75 .

As it is seen, there are a few studies directly related to valuation of erosion control, water and floods in Turkey. However, in Deniz (2012), Choice Experiments exercise was designed to estimate some of the expected consequences of Çakıt Stream Watershed Erosion Control Project, such as decreasing flood risk and soil erosion, increasing dam life and access to spring water. The Choice Experiments approach used by Deniz (2012) was the first application for this kind of problem in Turkey.

Şahin et al. (2018) determined values (timber, water, wildlife, and mushroom) provided by forest management regimes such as coppice forest and high forest. In the study, CEM was used. As a result, they found that total economic value provided by high forests is higher than coppice forests.

\section{Background}

The forest area of Turkey is approximately 22.3 million ha (GDF, 2015). Most of the forested area is under public ownership and wood production, i.e. a direct economic purpose, was the main driver of the mid-20 $0^{\text {th }}$ century programs. Later, ecological and social components, such as soil stabilization, hydrologic improvement, habitat rehabilitation, aesthetics, recreation, or the conservation of the environment, have progressively played a more prominent role in afforestation plans.

Afforestation programs enable to prevent soil erosion and flood risk, to produce water, to increase dam life, to sequester carbon, to contribute biodiversity, etc. Turkey has sensitive structure for floods and for erosion because of its geographical position, topography, hydrology, sloppy structure, semi-arid climate and soil conditions. Turkey's average altitude is $1132 \mathrm{~m}$ whereas Europe's average altitude is $330 \mathrm{~m}$. In Turkey, $46 \%$ of the total land has slope more than $40 \%$; $63 \%$ of the total land has slope more than $15 \%$. These figures reveal that Turkey is a mountainous and hilly country. Therefore, $3 / 4$ of Turkey's lands are exposed to severe and more severe erosion risk (MoFWA, 2013).

Floods have damaged the settlements and the agricultural areas in Turkey (most notably 
in $1952,1972,1980,1995)$, some having been more problematic than others have. Reforestation, erosion control, rehabilitation of degraded forest areas and pasture improvement studies have been carried out in 9.3 million ha ( $12 \%$ of the country) at the end of 2017 (GDCDE, 2020).

In Turkey, the Central Anatolia, the Southeastern Anatolia, the Aegean and the Southern regions (the Mediterranean Region) are shown as "high and very high vulnerable" on the Global Desertification Vulnerability Map (USDA, 2017). As approximately 85\% of the country being subject to erosion problems, the prevention of soil erosion and water related aspects are among the most important objectives of the new afforestation programs in arid and semi-arid regions, like the ones in Southern Turkey. $59 \%$ of agricultural lands; $54 \%$ of forest lands and 64 $\%$ of range lands are exposed to erosion in Turkey. Erosion precautions must be taken for forestlands including 3 million ha (MoFWA, 2013).

The soil amount transporting in Turkey with erosion in seas and lakes was as 500 million tons/year. However, the transported soil amount became as about 178 million tons/year with the control of erosion, reforestation, rehabilitation of degraded forest lands, pasture improvement, establishment of energy forests, artificial regeneration and special afforestation works, improvements in irrigation systems, technologies in agricultural lands and the ongoing rehabilitations (GDCDE, 2017).

Water is among the most critical natural resource to Turkey's economy and environment. There is about 112 billion $\mathrm{m}^{3}$ per year of economically exploitable water in Turkey. Freshwater consumption is approximately 44 billion $\mathrm{m}^{3}$ annually. Of this amount $74 \%$ is used for agriculture, $15 \%$ for domestic uses, and $11 \%$ for industrial needs. Water and water ecosystems such as lakes, coastal zones, and wetlands provide many benefits (e.g. flood protection, biodiversity conservation, pollution abatement, etc.). However, population growth, climate change and pollution of water bodies increase pressure on these resources (Croitoru et al., 2016). For that reason, the importance of erosion control and soil protection projects will continue and to select the best project among alternatives regarding market and nonmarket values will be problem for decision makers in Turkey.

\section{The Case Study Area: Çakıt Stream Watershed}

Çakıt Stream Watershed which is a subwatershed in Seyhan Basin, the upper part of it is in the Central Anatolia region which is a semi-arid land and the middle and lower parts are in the Mediterranean Region in the south of Turkey (Figure 1). Çakıt watershed is composed of five catchments and 24 sidestream catchments (GDF, 1988).

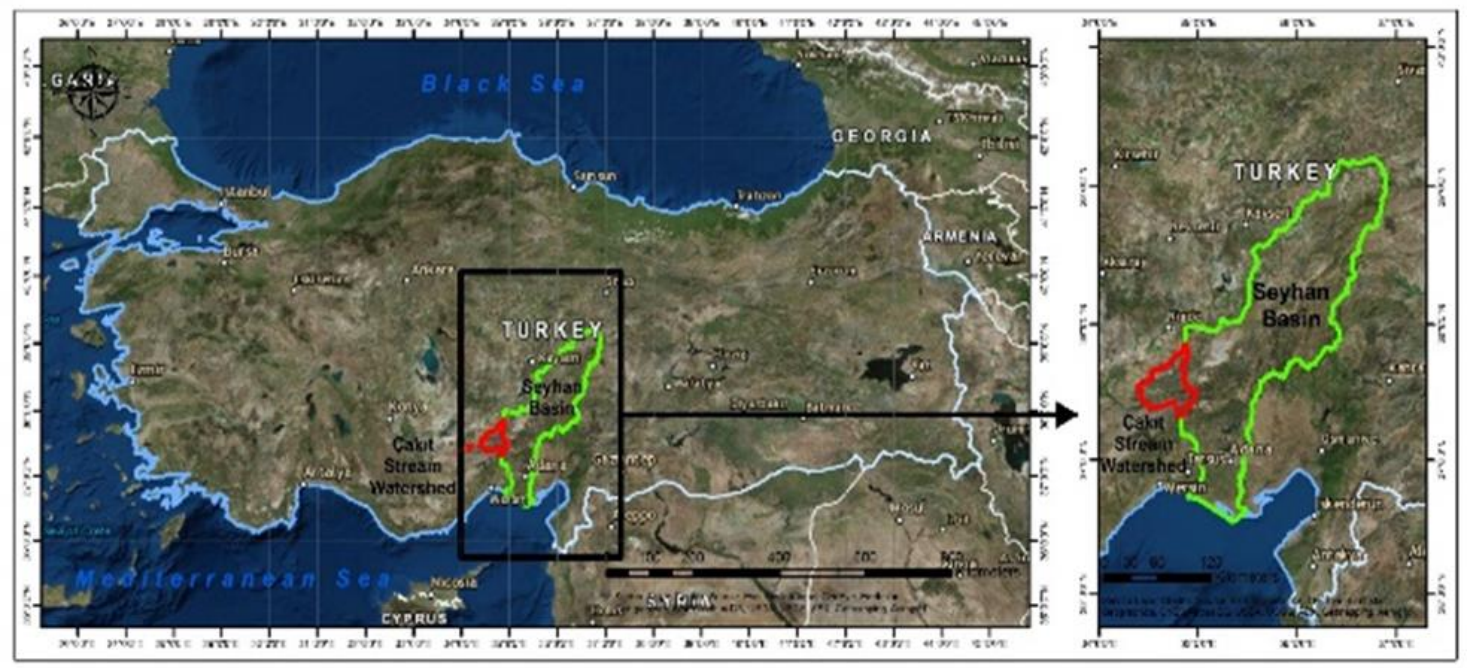

Figure 1. The location of the research area 
Erosion in Çakıt Stream Watershed was a widespread issue. Almost the whole study area (94\%) has been exposed to some degree of erosion, which has been severe in approximately $40 \%$ of the watershed (Deniz, 2012). Erosion in the region was mostly associated to the deficiency of plant cover. As a consequence, there was a higher risk of heavy rain resulting in floods.

In spring of 1980, heavy rains with melting ice and snow caused the sudden overflow of Çakıt Stream. The flood also damaged the highways, the railway, and other infrastructure. More dramatically, Seyhan Dam risked collapsing. To mitigate the problem, the floodgates of the dam had to be opened, moving sediments from upstream to downstream and damaging agricultural areas and the other dams downstream (GDF, 1988).

An associated problem was the supply of fresh water. Around $10 \%$ of households in the study area suffered shortages in the provision of quality spring waters due to the erosion problem in the region.

In response to these threats, Çakıt Stream Erosion Control Project was implemented from 1982 until 2016. The total area of Çakıt Watershed is 140056 ha. However, within the scope of the project, an area of approximately 40000 ha was worked.

In scope of the project, erosion control activities, rangeland rehabilitation and revegetation works were realized. The project substantially reached to its aims. Flood and erosion risk were completely finished in the watershed. Also, sediment accumulation in the dam decreased. In addition, rock and stone rolls on highways were controlled (MoFWA, 2013).

\section{Material and Methods}

In this study, the data collected by Deniz (2012) were used. Deniz (2012) had analyzed the data by using Multinomial Logit model (MNL). Deniz (2012) performed the analyses with payment, flood risk, erosion, dam, water by adding into the MNL model some socioeconomic variables (age, income, having children, education, the number of household members) and environmental variables (the answers of the questions "what is the most important environmental problem in the world" and "the first word questions that come to mind when hearing the word forest"). Thus, erosion problem, water word, and carbon word were used in the model. In the study, another Multinomial Logit model $\left(\mathrm{MNL}^{*}\right)$ and a Mixed Multinomial Logit Model (MMNL) were designed. While MNL model consists of variables mentioned above. $\mathrm{MNL}^{*}$ contains flood risk, erosion, dam life, water, payment, and status-quo variables. Therefore, MNL* is different from MNL in terms of the variables added into the model. MMNL model contains random (flood risk, erosion, dam life, water, and status-quo) and non-random parameters in the utility functions.

In a CEM exercise, individuals are asked to identify their preferred choice $i$ from a given set of $J$ alternatives. The data analysis follows a Random Utility Maximization model (RUM) (McFadden, 1974). Under RUM, it is assumed that the observed choice from individual $n$ is the one she expected to provide her with the highest utility. Her utility function, $U_{n i}$, can be decomposed into a systematic part, $V_{n i}$, and a stochastic part, ${ }_{n i}$ . If $\varepsilon_{n i}$ is assumed to be an independently and identically distributed extreme value type I, this probability has a closed form expression, known as logit choice probability $(\mathrm{P})$ :

$P_{n i}=\frac{\mathrm{e}^{\beta^{\prime} x_{n i}}}{\sum_{j} \mathrm{e}^{\beta^{\prime} x_{n j}}}$

where $x$ is a vector of variables, and $i$ and $j$ are elements of the set of $J$ alternatives in (1).

The standard MNL has some limitations, which are extensively discussed in Train (2003). The main ones are that MNL (i) exhibits the property of independence from irrelevant alternatives; (ii) it represents the systematic taste variation, but not random taste variations; and (iii) it cannot handle situations where the unobserved part of the utility function is correlated over time.

An alternative to overcome these limitations is to use a MMNL. Mixed logit probabilities can be expressed as the integrals of standard logit probabilities over a density of parameters. Following Train (2003), a 
mixed logit model is a model in which choice probabilities take the form

$$
P_{n i}=\int \frac{\mathrm{e}^{\beta_{n}^{\prime} x_{n i}}}{\sum_{j} \mathrm{e}^{\beta_{n}{ }_{n} x_{n j}}} \Phi(\beta \mid b, \Omega) \mathrm{d} \beta,
$$

Where $\frac{\mathrm{e}^{\beta_{n}^{\prime} x_{n i}}}{\sum_{j} \mathrm{e}^{\beta_{n}^{\prime} x_{n j}}}$ is a standard logit formula, $\varphi(\beta \mid b, \Omega)$ is the density of the random coefficients with mean $b$ and covariance matrix $\Omega$. For example, the logit expression in (1) can be treated as a special case of mixed logit with $\beta$ being fixed. Limitation (ii) of the standard MNL is relaxed by assuming a mixing distribution that is not degenerated at fixed parameters. That is, that preference parameters vary across respondents according to an assumed distribution. In our exercise, all random parameters apart from cost coefficient, which was assumed to be fixed, were assumed to follow normal distribution.

Since in the exercise reported here each individual faced several choices, we accounted for dependence across repeated choices from the same respondent by specifying a panel version of the MMNL, which overcomes MNL limitation (iii). Conditional on $\beta$, the probability that individual $n$ makes a sequence of $T$ choices is the product of logit formulas integrated over all possible values of $\beta_{n}$, i.e.

$$
P_{n i}=\int \prod_{t=1}^{T}\left\lfloor\frac{e^{\beta_{n}^{\prime} x_{n i t}}}{\sum_{j} e^{\beta_{n}^{\prime} x_{n j t}}}\right\rfloor \varphi(\beta \mid b, \Omega) \mathrm{d} \beta
$$

After the parameter estimates have been obtained, the marginal WTP for each attribute in the model calculated by Eq. (4) (Hensher et al. 2005; Japelj et al. 2012; Farreras et al. 2017):

Marginal WTP $($ implicit price $)=-\frac{\beta \text { attribute }}{\beta \text { payment }}$

In Eq. (4), ßattribute is the coefficient on the attribute of interest and $\beta$ payment is the cost coefficient, which can be interpreted as marginal value of money. The ratio can be interpreted as willingness to pay for a given attribute level.

For the CEM exercise, the general information on the watershed was collected to prepare survey. Firstly, the main project document and several reports related to the watershed were examined. The experts and the scientists were interviewed in the area. The several photos were taken from the watershed to use in the choice cards. With this information, the attributes to be valued by the method and their levels were determined regarding the aims of the project and other data obtained from the research area and experts. Choice cards are the main material of the CEM and prepared by researchers for this study.

In this context, four attributes were considered in the survey: a reduction in the risk of flood occurrences, a decrease in the rate of erosion, an extension of the service time of the dams, and an increase in the provision of spring water. The annual payment (cost) defines the WTP of respondents is an important variable in CEM. The descriptions of the attributes, their levels and annual payments obtained from special survey are reported in Table 1.

The questionnaire which was another material of the study was organized in three parts, an introduction, the valuation exercise, and socioeconomic information. The research area and the aim of the valuation exercise were briefly explained in the introduction. In this part, the map of the watershed was showed to the respondents to understand the limitations of the project and two questions were asked to learn the priority of environmental problems and the feelings on "forest" word.

In the central part of the main survey, eleven debriefing questions such as knowledge of the erosion control activities in the region, source of the drinking water, experiences on flood or erosion problem were asked. In this section, four cards which explain the statement of the attributes were showed together with related the questions. The cards were generated from pictures in Figure 2 regarding the context of the question. To generate different scenarios which can 
define different levels of attributes and amounts of annual payments, 16 choice cards were prepared and located in the central part of the main survey. Each card contains three alternatives such as the status quo, alternative 1, alternative 2, as seen in Figure 2. The most preferred alternative among the alternatives in each card were asked to respondents. In the final part of the main survey, there were six questions to collect data on the socioeconomic characteristics of the respondents.
A pilot survey applied with 30 respondents was conducted to test whether the survey instrument can be used to elicit respondents' preferences. The main survey of the study was undertaken from August to October 2011 in the form of face-to-face interviews with total 300 households (respondents) from the two provinces, Adana and Niğde, in the watershed. The interviews took an average of 20 minutes.

Table 1: Attributes and levels used in the valuation exercise (Deniz, 2012)

\begin{tabular}{|c|c|c|}
\hline Attributes (variables) & Descriptions & Levels \\
\hline $\begin{array}{l}\text { Flood Risk } \\
\text { (FLOOD) }\end{array}$ & $\begin{array}{l}\text { The settlements and the agricultural fields of the } \\
\text { region will experience a severe flood every }\end{array}$ & $\begin{array}{r}5 \text { years }(\mathrm{SQ}) \\
55 \text { years } \\
105 \text { years }\end{array}$ \\
\hline $\begin{array}{l}\text { Soil Erosion } \\
(\text { EROSION) }\end{array}$ & $\begin{array}{l}\% \text { of the region that will be protected from severe } \\
\text { soil erosion }\end{array}$ & $\begin{array}{r}0 \%(\mathrm{SQ}) \\
20 \% \\
40 \%\end{array}$ \\
\hline $\begin{array}{l}\text { Dam Life } \\
\text { (DAM) }\end{array}$ & $\begin{array}{l}\text { The capacity of the main dam in the river will be } \\
\text { compromised due to soil erosion after }\end{array}$ & $\begin{array}{r}50 \text { years }(\mathrm{SQ}) \\
250 \text { years, } \\
450 \text { years }\end{array}$ \\
\hline $\begin{array}{l}\text { Access to Spring Water } \\
\text { (WATER) }\end{array}$ & $\begin{array}{l}\text { The percentage of people with access to quality } \\
\text { spring waters could be }\end{array}$ & $\begin{array}{r}10 \%(\mathrm{SQ}) \\
50 \% \\
90 \%\end{array}$ \\
\hline $\begin{array}{l}\text { Annual Payment } \\
\text { (COST) }\end{array}$ & Cost (も/year) for 5 years & $\begin{array}{r}\text { も0 (SQ) } \\
\text { も100 } \\
\text { も200 } \\
\text { も300 } \\
\text { も400 }\end{array}$ \\
\hline
\end{tabular}

$\mathrm{SQ}=$ status quo situation

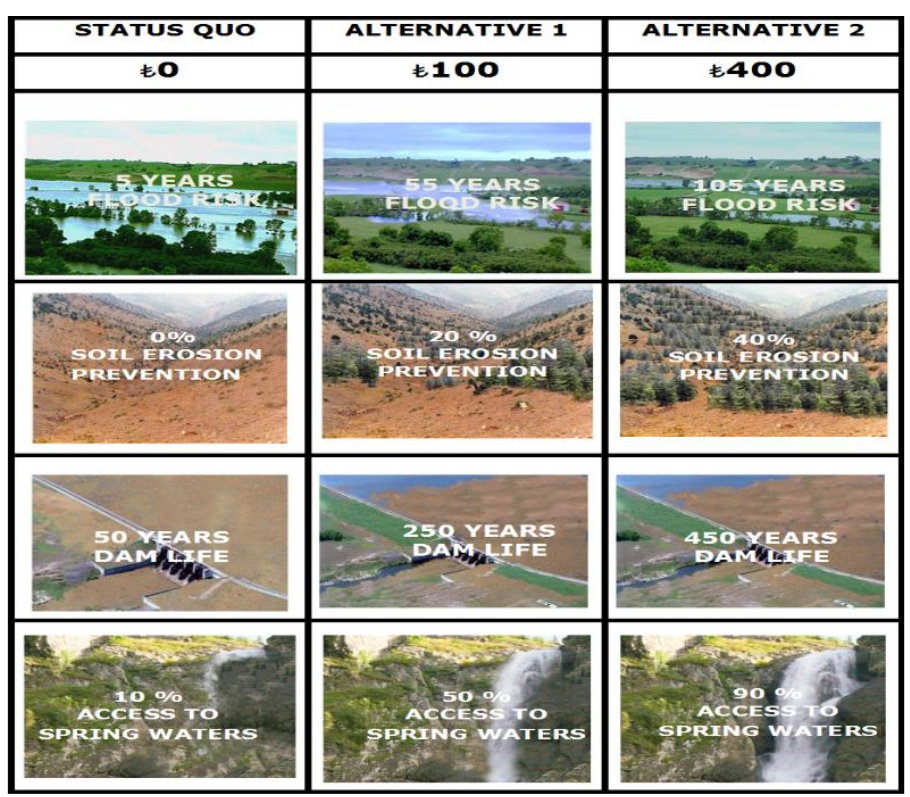

Figure 2. Example of a choice card (Deniz, 2012) 


\section{Results and Discussion}

To compare the results of MNL in Deniz (2012), in this study, firstly, a basic MNL* model with no random taste heterogeneity was solved. Secondly, a MMNL model allowing random taste heterogeneity in all nonmonetary attributes computed. All nonmonetary parameters were assumed to be normally distributed, and the cost was assumed to be fixed.

The MMNL model with fixed cost uses 5 additional parameters compared to the $\mathrm{MNL}^{*}$ model, namely the standard deviations of all non-monetary attributes. Using these 5 additional parameters leads to a large improvement in log-likelihood by 2201.8 units, which is significant at high levels of confidence. These results indicate that there is a very large preference heterogeneity in the studied sample. Giergiczny \& Kronenberg (2014), used CEM to estimate the value of street trees in the city center of Lodz, Poland. In the study, MNL and MMNL model were used. Similarly our study, it was obtained a very large improvement in log likelihood by 2051.8 units when moving from MNL to MMNL.

The modelling results are presented in Table 2. The signs of means are the same in both models, and are consistent with a priori expectations. The estimate for the SQ (status quo) constant is negative, indicating that, on average, respondents would like to move from the current situation to an afforestation programme. The positive and statistically significant estimates for the non-monetary attributes imply that respondents prefer lower levels of flood risk over time, larger parts of the region being protected from a severe soil erosion, a larger percentage of people with access to quality spring waters and tend to prefer programs in which the life of the dam is extended. Finally, and as expected, the estimate for "Cost" as a fixed parameter is negative, indicating that respondents are less inclined to favour the program as its cost increases.

However, according to results of the MNL in Deniz (2012), the sign and coefficient of the life of dam is negative (-0.00109). There can be several reasons of this. When Deniz asked the respondents, they answered that the dam was working very good and they did not worry about it. Therefore, they did not willing to pay for the dam. However, as can be seen from Table 2, it was found that when another MNL model was run by subtracting socio-economic variables from the model, the value of the dam life could return to positive (0.11526). Moreover, in MMNL model, the finding for the dam life variable is positive (0.16127) too. At this point, it can be seen that model differentiation may change the findings on value.

Table 2. Estimations of the models

\begin{tabular}{|c|c|c|c|c|c|c|c|c|}
\hline \multirow{2}{*}{$\begin{array}{l}\text { Attributes } \\
\text { /Statistics }\end{array}$} & \multicolumn{2}{|c|}{ MNL } & \multicolumn{2}{|c|}{$\mathrm{MNL}^{*}$} & \multicolumn{4}{|c|}{ MMNL } \\
\hline & Mean & $\begin{array}{l}\text { Standard } \\
\text { error }\end{array}$ & Mean & $\begin{array}{l}\text { Standard } \\
\text { error }\end{array}$ & Mean & $\begin{array}{l}\text { Standard } \\
\text { error }\end{array}$ & $\begin{array}{l}\text { Standard } \\
\text { deviation }\end{array}$ & $\begin{array}{l}\text { Standard } \\
\text { error }\end{array}$ \\
\hline Cost & $-0.00443^{* * *}$ & 0.00022 & $-0.41279^{* * * *}$ & 0.01940 & $-0.60354^{* * * *}$ & 0.02792 & - & - \\
\hline Flood & $0.00511^{* * *}$ & 0.00134 & $0.36764^{* * * *}$ & 0.10482 & $0.45028^{* *}$ & 0.19822 & $2.07530^{* * * *}$ & 0.21073 \\
\hline Erosion & $0.01961^{* * * *}$ & 0.00263 & $1.60537^{\text {**** }}$ & 0.21942 & $2.32879^{\text {*** }}$ & 0.34380 & $2.92050^{* * *}$ & 0.41789 \\
\hline Dam & $-0.00109^{* * * *}$ & 0.00024 & $0.11526^{\text {**** }}$ & 0.02253 & $0.16127^{* * * *}$ & 0.03021 & $0.10957^{* *}$ & 0.05172 \\
\hline Water & $0.00942^{* * *}$ & 0.00127 & $0.73455^{\text {**** }}$ & 0.11113 & $1.19665^{\text {**** }}$ & 0.25013 & $3.25005^{* * *}$ & 0.23920 \\
\hline SQ & $-1.27161^{* * * *}$ & 0.61924 & -0.15100 & 0.16520 & $-41.9427^{\text {**** }}$ & 5.65412 & $69.2054^{* * *}$ & 9.07253 \\
\hline LL & \multicolumn{2}{|c|}{-2793.0557} & \multicolumn{2}{|c|}{-4585.21943} & \multicolumn{4}{|c|}{-2383.39719} \\
\hline Pseudo-R $^{2}$ & \multicolumn{2}{|c|}{0.2514} & \multicolumn{2}{|c|}{0.0719} & \multicolumn{4}{|c|}{0.548} \\
\hline $\mathrm{N}$ & \multicolumn{8}{|c|}{4800} \\
\hline
\end{tabular}

As seen from Table 2, model change did not only affect the signs and size of the attributes, but also the determination of the models changed. Differentiation of MNL model using different variables caused Pseudo-R2 to decrease from 0.2514 to 0.0719 . When the MMNL model was used, a bigger Pseudo-R2 (0.548) could be obtained. 
In Table 3, we present WTP estimates for the models. As seen from Table 2, the MMNL model gives results much better fit statistically. The different models would produce different WTP estimations. According to MNL* Model estimations, the
WTP for decreasing the flood risk by 1 year is $0.89 £ /$ person based. This means that respondents on average would be willing to pay $89.06 € /$ person for moving from the base level (SQ) to the highest level shown in the questionnaire.

Table 3. WTP estimates for all models

\begin{tabular}{|c|c|c|c|c|c|c|c|c|}
\hline \multirow[b]{2}{*}{ Attributes } & \multicolumn{2}{|c|}{ MNL } & \multicolumn{2}{|c|}{$\mathrm{MNL}^{*}$} & \multicolumn{4}{|c|}{ MMNL } \\
\hline & $\begin{array}{l}\text { Mean } \\
\text { WTP }\end{array}$ & $\begin{array}{c}\text { Standard } \\
\text { error }\end{array}$ & $\begin{array}{l}\text { Mean } \\
\text { WTP }\end{array}$ & $\begin{array}{c}\text { Standard } \\
\text { error }\end{array}$ & $\begin{array}{l}\text { Mean } \\
\text { WTP }\end{array}$ & $\begin{array}{c}\text { Standard } \\
\text { error }\end{array}$ & $\begin{array}{l}\text { Standard } \\
\text { deviation }\end{array}$ & $\begin{array}{c}\text { Standard } \\
\text { error }\end{array}$ \\
\hline Flood & 1.154 & $\mathrm{Nc}$ & $0.89062^{* * *}$ & 0.26940 & $0.74606^{* *}$ & 0.33768 & $3.43853^{* * *}$ & 0.32645 \\
\hline Erosion & 4.426 & $\mathrm{Nc}$ & $3.88907^{* * *}$ & 0.52335 & $3.85853^{* * *}$ & 0.54579 & $4.83891^{* * * *}$ & 0.66618 \\
\hline Dam & -0.25 & $\mathrm{Nc}$ & $0.27922^{* * *}$ & 0.05773 & $0.26721^{* * *}$ & 0.05266 & $0.18154^{* *}$ & 0.08691 \\
\hline Water & 2.126 & $\mathrm{Nc}$ & $1.77948^{* * *}$ & 0.26606 & $1.98271^{* * *}$ & 0.41307 & $5.38495^{* * * *}$ & 0.50665 \\
\hline SQ & -287.05 & $\mathrm{Nc}$ & -0.36581 & 0.39642 & $-69.4941^{* * *}$ & 9.72171 & $114.665^{* * * *}$ & 15.65414 \\
\hline
\end{tabular}

Erosion turned out to be a highly valued attribute that is an increase by $1 \%$ soil erosion prevention is worth $3.89 € /$ person. This implies that respondents would be willing to pay $155.56 \notin$ for moving from the SQ level $(0 \%)$ to the highest level (40\%). The WTP for increasing dam life by 1 year is worth 0.28 $£ /$ person what in the case of this attribute implies that on average respondents would be willing to pay 111.69 ₹ for moving from the SQ level (50 years) to the highest level (450 years). Finally, the WTP for increasing the access to the spring water by $1 \%$ is 1.78 €/person which would translate to WTP equal to $142.36 €$ if change from the level (10\%) to the $90 \%$ is considered. Finally, we see that the WTP for the alternative specific constant for a program implementation is $0.37 € /$ person.

By MMNL Model, the WTP for decreasing the flood risk by 1 year is 0.74 $€ /$ person based. This means that respondents on average would be willing to pay $74 €$ for moving from the base level (SQ) to the highest level shown in the questionnaire. Erosion turned out to be a highly valued attribute that is an increase by $1 \%$ soil erosion prevention is worth $3.85 € /$ person. This implies that respondents would be willing to pay $154.34 €$ for moving from the SQ level $(0 \%)$ to the highest level (40\%). The WTP for increasing dam life by 1 year is worth 0.26 £/person what in the case of this attribute implies that on average respondents would be willing to pay 106.88 ₹ for moving from the SQ level (50 years) to the highest level (450 years). Finally, the WTP for increasing the access to the spring water by $1 \%$ is $1.98 € /$ person which would translate to WTP equal to $158.61 €$ if change from the level (10\%) to the $90 \%$ is considered. Finally, we see that the WTP for the alternative specific constant for a program implementation is $69.49 \mathrm{f} /$ person.

According to MNL Model in Deniz (2012) determined that the value of 1 year prevention of floods is $1.15 € /$ person; the value of $1 \%$ prevention of soil erosion is $4.43 \mathrm{E} /$ person; the value of 1 year increase for dam life is -0.25 $€ /$ person and the value of $1 \%$ increase for access to spring water is $2.13 € /$ person in 2012 prices by using MNL model. This means that respondents on average would be willing to pay $115 €$ for moving from the base level (SQ) to the highest level shown in the questionnaire. Erosion turned out to be a highly valued attribute that is an increase by $1 \%$ soil erosion prevention is worth 4.43 $£ /$ person. This implies that respondents would be willing to pay $177 £$ for moving from the SQ level (0\%) to the highest level (40\%). The WTP for increasing dam life by 1 year is worth $-0.25 € /$ person what in the case of this attribute implies that on average respondents would be willing to pay $-100 €$ for moving from the SQ level (50 years) to the highest level (450 years). The reason of negative WTP is the respondents said that the dam was working very well and they did not worry about the dam. So, they did not want to pay for the dam. Interestingly, WTP for dam life 
were computed as positive by using MNL* and MMNL models.

Finally, the WTP for increasing the access to the spring water by $1 \%$ is $2.13 € /$ person which would translate to WTP equal to $170 €$ if change from the level (10\%) to the $90 \%$ is considered. Lastly, the WTP for the alternative specific constant for a program implementation is $287.05 \mathrm{f} /$ person.

The WTP estimations for flood have same sign in MNL, MNL ${ }^{*}$ and MMNL models. But, the level of WTP in MNL (1.154) decreased in $\mathrm{MNL}^{*}(0.890)$ and in MMNL $(0.746)$. In the same way, WTP estimations for erosion have same sign in the MNL, MNL* and MMNL models. But, the level of WTP in MNL (4.426) decreased in $\mathrm{MNL}^{*}$ (3.89) and in MMNL (3.86). While the signs of WTP estimation of dam life are positive (0.28 and $0.27)$ in $\mathrm{MNL}^{*}$ and MMNL models, it has negative sign (-0.25) in MNL model in Deniz (2012). As it seen, when models change, signs can change too. WTP estimations for water have same sign in the MNL, MNL* and MMNL models. However, the level of WTP in MNL (2.126) decreased in $\mathrm{MNL}^{*}$ (1.78) and MMNL (1.98).

\section{Conclusion}

In this study, the different models were tried to determine the value of ecosystem services provided by forest resources in scope of CEM. In the study, the value of erosion control service which one of the non-market services of forest ecosystems was tried to be determined. Deniz (2012) calculated this value for Çakıt Stream Watershed before by using MNL model. In our study, we tried MNL* and MMNL models for same watershed. These findings prove that the models can affect the values attributed by the same respondents.

The MNL model used by Deniz (2012) has some limitations mentioned before. The different models would produce different WTP estimations. Although the results of Deniz (2012) and our study used different models are similar to each other. We can say that $\mathrm{MNL}^{*}$ and MMNL could produce different coefficients and signs for values but the magnitude order of the values is the similar. While the value of prevention of soil erosion was found as the highest value, the lowest one is the value to increase the dam life in both studies.

When the model used changes, it was seen that the values of Pseudo- $\mathrm{R}^{2}$ changes. Our study, a bigger Pseudo- $\mathrm{R}^{2}$ (0.548) was obtained with MMNL model. Thus, among the models, MMNL was found to be the best explanatory model. Similarly, Giergiczny \& Kronenberg (2014) found that the Pseudo- $\mathrm{R}^{2}$ of MMNL is bigger (0.4692) than MNL model (0.1471).

Giergiczny et al. (2015) assessed the public preferences for forest structural attributes using CEM. In the study, both MNL and MMNL models were applied to the data. It was found that the Pseudo- $\mathrm{R}^{2}$ of MMNL is bigger (0.2586).

Brus et al. (2016) monitored the changes in habitat types by producing sequential maps based on point information followed by mapping using a multinomial logit regression model with abiotic variables. The results showed that the MMNL model fitted significantly better than the MNL model with the same fixed effects. Pseudo- $R^{2}$ for the MMNL model was 0.467 , versus 0.395 for the MNL model.

The significance of a model can also be understood by looking at the log-likelihood values except for Pseudo- $\mathrm{R}^{2}$. Comparing to MNL model, generally, in MMNL model, Pseudo- $\mathrm{R}^{2}$ and log-likelihood values are high. This situation was stated with the results of our study and similar studies.

Calculating the values of ecosystem services are important for an efficient management of forest resources. Approaches and methods used by valuation studies are specific for each case. Even so the results obtained are specific to every watershed, they are important in providing data to shed light on effective resource management. Especially, it is vital on resource allocation. We recommend that the usage of non-market valuation techniques for decision making by generating site specific approaches. But, we never suggest any specific model for any valuation problem. Although the techniques and models can affect the estimations, different models can be used as sensitivity analysis to understand dominant alternative in decision making problem. An alternative 
model must be used to test results of the model computed firstly.

\section{References}

Bann, C. \& Clemens, M. (2001). Turkey: forest sector review-global overlays program final report (in Turkish). Isir Publisher, Ankara.

Brus, D. J., Slim, P.A., Gort, G., Heidema, A.H. \& Van Dobben, H. (2016). Monitoring habitat types by the mixed multinomial logit model using panel data, Ecological Indicators, 67, 108-116.

Can, Ö. \& Alp, E. (2012). Valuation of environmental improvements in a specially protected marine area : A choice experiment approach in Göcek Bay Turkey. Science of Total Environment, 439, 291-298.

Croitoru, L., Bahar-Divrak, B. \& Xie, J. (2016). Valuing water resources in Turkey : A case study of Beyşehir Lake. Journal of Environmental Protection, 2016, 7, 19041922.

Deniz, T. (2012). Valuation in erosion control activities (in Turkish), Istanbul University, Natural and Applied Science Institution, Doctorate Thesis, July 2012, Istanbul.

Farreras, D., Riera, P. \& Salvador, P. F. (2017). Environmental valuation with periodical payments in high-inflation economies. An Argentinean case study, Ecological Economics, 138, 56-63.

GDAEC (2008). GDAEC Activities, General Directorate of Afforestation and Erosion Control, Ankara.

GDCDE. (2017). General Directorate of Combating Desertification and Erosion Official Website, www.cem.gov.tr

GDCDE. (2020). Documents: Erosion in Turkey, General Directorate of Combating Desertification and Erosion Official Website, www.cem.gov.tr

GDF. (1988). Adana Çakıt stream erosion control project (in Turkish), General Directorate of Forestry, Ministry of Agriculture, Forestry and Rural Affairs, Project No: 2, Ankara.

GDF. (2015). Turkey Forests, General Directorate of Forestry Official Website, www.ogm.gov.tr

Giergiczny, M., Czajkowski, M., Żylicz, T. \& Angelstam, P. (2015). Choice experiment assessment of public preferences for forest structural attributes, Ecological Economics, $119,8-23$

Giergiczny, M. \& Kronenberg, J. (2014). From valuation to Governance: Using choice experiment to value street trees. AMBIO, 43, 492-501.

Gürlük, S. \& Ward, F. (2009). Integrated basin management: Water and food policy options for Turkey. Ecological Economics, 68, 26662678.

Hensher, D., Rose, J.M. \& Greene, W.H. (2005). Applied choice analysis, Cambridge University Press, https://doi.org/10.1017/CBO9780511610356

Japelj, A., Mavsar, R. \& Kovač, M. (2012). The economic value of selected ecosystem services in Slovenia, IUFRO 4.05.00 International Symposium - Criteria and Indicators for Sustainable Forest Management: Contributions of Managerial Economics and Accounting, at: Knoxville, Tennessee, USA.

Kaya, G., Ok, K., Porsuk, T., Deniz, T. \& Çetiner, M. (2018). Estimating regional recreational demand for forest recreation sites with travel cost method in Ankara province, Journal of Forestry Research 2018, 5:1, 15-30, DOI: 10.17568/ogmoad.361810.

Kaya, G. \& Özyürek, E. (2016). Economic value estimation of scenic beauty of METU Forest in the context of urban forest, Journal of Forestry Research, 2015/1, A, 1:2, 15-28, DOI: 10.17568/oad.69943.

McFadden, D. (1974). Conditional logit analysis of qualitative choice behavior, In : Zarembka, P. (Ed.), Frontiers in econometrics: 105-142. Academic Press, New York, USA.

MoAF. (2019). Strategic plan of ministry of forestry and water affairs (2019-2023) (in Turkish), Ankara.

MoEF. (2004). National Forestry Program of Turkey (2004-2023) (in Turkish), Ministry of environment and forestry, October 2014, Ankara.

MoFWA. (2013). Action plan of upstream flood control (2013-2017) (in Turkish), Ministry of Forestry and Water Affairs, Ankara.

Özdemir, F. Y. \& Baycan-Levent, T. (2010). A Contingent valuation approach to communitybased watershed management in Beyşehir Lake Basin. Conference Paper at the 50th Congress of the European Regional Science Association:Sustainable Regional Growth and Development in the Creative Knowledge Economy", 19-23 August 2010, Jönköping, Sweden.

Özmış, M. \& Tolunay, A. (2017). Determining the economic value of erosion control services and willingness to payment trends of society at Burdur region (in Turkish), Süleyman Demirel University, Journal of Natural and Applied Sciences, 21(1), 99-112,

Pak, M. (2002). A study on the estimation of economic value of recreational benefit from forest resources and effective variables on the estimated value (East mediterranean and east black sea region forest recreation sites sample) 
(in Turkish). Karadeniz Technical University, Natural and Applied Science Institute, December 2002, Trabzon.

Pak, M., Türker, M.F. \& Öztürk, A. (2010). Total economic value of forest resources in Turkey, African Journal of Agricultural Research, 5(15), 1908-1916.

Pehlivanoğlu, N. (2010). Economic valuation of maintaining water quality in Bartın River Bartın University, Natural and Applied Science Institute, MSc thesis, Ağustos 2010, Bartın.

Şahin, A., Deniz, T., Kaya, G. \& Ok, K. (2018). Economic Analysis of Forest Management Regimes Using Choice Experiments Method : The Case of Pabuçdere Basin, Research Project, Project Number: 10.3301/2014-2017, İstanbul.

Tolun, L., Ergenekon, S., Murat Hocaoglu, S., Suha Donertas, A., Cokacar, T., Husrevoglu, S., Polat Beken, C. \& Baban, A. (2012).
Socioeconomic response to water quality : A first experience in science and policy integration for the Izmit Bay Coastal System. Ecology and Society, 17, 40.

Train, K. (2003). Discrete choice methods with simulation, Cambridge : Cambridge UP.

Türker, M. F., Pak, M. \& Öztürk, A. (2005). Valuing Mediterranean Forests : Towards total economic value; Merlo and Croitoru, L. (eds), CABI publishing Oxford.

USDA. (2017). Global desertification vulnerability map, U.S. Department of Agriculture Natural Resources Conservation Service. Soil Survey Division. World Soil Resources, U.S. Department of Agriculture official website.

https://www.nrcs.usda.gov/wps/portal/nrcs/det ail/soils/use/worldsoils/?cid=nrcs142p2_0540 $\underline{03}$ 